\title{
Trilobatin ameliorates insulin resistance through IRS-AKT-GLUT4 signaling pathway in C2C12 myotubes and ob/ob mice
}

Min Liu ${ }^{1,2}$, Lujing Wang ${ }^{1,2}$, Xigan Li $i^{1,2}$, Yucui Wu ${ }^{1,2}$, Fei Yin ${ }^{1,2^{*}}$ and Jianhui Liu ${ }^{1,2^{*}}$

\begin{abstract}
Background: Trilobatin, a natural compound, has been found to exhibit anti-diabetic properties in high-fat diet (HFD) and streptozotocin (STZ) induced type 2 diabetic mice. But up to now no research has been reported on the effect of trilobatin on insulin resistance in peripheral tissues. Herein, we determined the effects of trilobatin on insulin resistance in palmitate-treated C2C12 myotubes and ob/ob mice.

Methods: Male ob/ob mice (8-10 weeks) and same background C57BL/6 mice were used to evaluate the role of trilobatin on insulin resistance; protein expression and phosphorylation were measured by western blot; glucose uptake was determined a fluorescent test.

Results: Treatment with trilobatin prevented palmitate-induced insulin resistance by enhancing glucose uptake and the phosphorylation of insulin resistance substrate 1 (IRS1) and protein Kinase B, (PKB/AKT), recovered the translocation of GLUT4 from cytoplasm to membrane, but preincubation with LY294002, an inhibitor of PI3K, blocked the effects of trilobatin on glucose uptake and the distribution of GLUT4 in C2C12 myotubes. Furthermore, administration with trilobatin for 4 weeks significantly improved insulin resistance by decreasing fasting blood glucose and insulin in serum, enhancing the phosphorylation of IRS1 and AKT, and recovering the expression and translocation of GLUT4 in ob/ob mice.
\end{abstract}

Conclusions: IRS-AKT-GLUT4 signaling pathway might be involved in trilobatin ameliorating insulin resistance in skeletal muscle of obese animal models.

Keywords: Glucose transporter 4 (GLUT4), Insulin receptor substrate 1 (IRS1), Insulin resistance, Protein kinase B (PKB/ AKT), Trilobatin

\section{Highlights}

Trilobatin improves insulin resistance in skeletal muscle.

Trilobatin enhances glucose uptake in insulin-resistant $\mathrm{C} 2 \mathrm{C} 12$ myotubes.

\footnotetext{
*Correspondence: fyin@cqut.edu.cn; jhliu@cqut.edu.cn

${ }^{1}$ Chongqing Key Lab of Medicinal Chemistry \& Molecular Pharmacology,

Chongqing University of Technology, Hongguang Road 69, Ba'nan District, Chongqing 400054, China

Full list of author information is available at the end of the article
}

IRS-AKT-GLUT4 signaling pathway is involved in trilobatin improving insulin resistance.

\section{Background}

Increasing evidence indicates that obesity and type 2 diabetes has elevated over years in both developing and developed country, which are closely associated with insulin resistance, a pathophysiological condition characterized by an impaired insulin action in insulin-sensitizing tissues including liver, adipose tissue and skeletal muscle [1, 2]. Skeletal muscle accounts for $40 \%$ of body

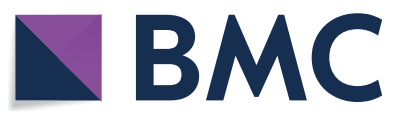

(c) The Author(s) 2020. This article is licensed under a Creative Commons Attribution 4.0 International License, which permits use, sharing, adaptation, distribution and reproduction in any medium or format, as long as you give appropriate credit to the original author(s) and the source, provide a link to the Creative Commons licence, and indicate if changes were made. The images or other third party material in this article are included in the article's Creative Commons licence, unless indicated otherwise in a credit line to the material. If material is not included in the article's Creative Commons licence and your intended use is not permitted by statutory regulation or exceeds the permitted use, you will need to obtain permission directly from the copyright holder. To view a copy of this licence, visit http://creativeco mmons.org/licenses/by/4.0/. The Creative Commons Public Domain Dedication waiver (http://creativecommons.org/publicdomain/ zero/1.0/) applies to the data made available in this article, unless otherwise stated in a credit line to the data. 
weight in humans, and is responsible for up to $80 \%$ insulin-mediated glucose disposal under normal physiological conditions [3, 4]. To date, the role of skeletal muscle in glucose homeostasis has been widely reported in insulin resistance in both cellular and animal disease models [5-7]. However, although an enormous amount of mechanisms of insulin resistance has been postulated in skeletal muscle, the promising compounds are still needed to be explored.

Trilobatin, isolated from the leaves of Lithocarpus polystachyus Rehd, is a natural sweetener [8]. It has been shown that trilobatin has anti-oxidative $[9,10]$, anti-viral and anti-inflammatory activities $[11,12]$. Trilobatin also exhibits anti-hyperglycemic properties by accelerating liver glycogen synthesis, decreasing oxidative stress, increasing the expression of glucokinase, and up-regulating the expression of insulin receptor substrate (IRS) on long-term double high-fat diet and streptozotocin (STZ) induced type 2 diabetic mice [13]. Similar to other dihydrochalcones, phlorizin (a dual SGLT1/SGLT2 inhibitor) [14], phloretin (a GLUT2 inhibitor) [15], and acarbose (an alpha-glucosidase inhibitor) [16, 17], our previous works demonstrated that trilobatin could be bind with SGLT1/2 [18]. But up to now, the effect of trilobatin on insulin resistance is still needed to be identified.

In the present study, the effects of trilobatin on glucose uptake and insulin resistance and the underlying mechanisms were investigated in palmitate-treated $\mathrm{C} 2 \mathrm{C} 12$ myotubes and ob/ob mice, especially for the regulation of trilobatin on the phosphorylation of insulin receptor substrate (IRS) and PI3K/AKT, and the expression and translocation of glucose transporter 4 (GLUT4) in cellular and animal disease models of insulin resistance.

\section{Methods}

\section{Materials}

Trilobatin, palmitate, DAPI and (2-( $N$-(7-nitrobenz2-oxa-1,3-diazol-4-yl) amino)-2-deoxyglucose (2NBDG) uptake measurement kits were purchased from Sigma (St. Louis, MO, USA). IRS1, p-IRS1 (Ser 612), p-IRS1 (Ser 307), Akt, p-Akt (Ser 473), p-Akt (thr308), Na, K-ATPase, MYH1, MYOD1, and $\beta$-actin primary antibodies were bought from Cell Signaling Technology (Danvers, MA, USA). GLUT4 antibody was obtained from Abcam (Cambridge, MA, USA). HRP-conjugated GAPDH primary antibody was purchased from Aksmics (shanghai, China), Specific anti-mouse and anti-rabbit HRP-conjugated second antibodies were obtained from Santa Cruz Biotechnology (Texas, CA, USA). Rat/mouse insulin ELISA kits (EZRMI-13K) and ECL chemiluminescence detection reagent were obtained from Millipore (Billerica, MA, USA). Plasma membrane protein extraction kit, nuclear/cytosolic fractionation kit, RIPA buffer and BCA protein assay kit and other chemicals were purchased from Beyotime (Shanghai, China).

\section{Cell culture}

Mouse skeletal muscle cell lines, C2C12 myoblasts, were obtained from American Type Culture Collection (ATCC, Manassas, VA, USA) and maintained in DMEM supplemented with $10 \%$ FBS, and $1 \%$ penicillin/streptomycin $(\mathrm{P} / \mathrm{S})$ at $37{ }^{\circ} \mathrm{C}$ in a humidified incubator with $5 \%$ $\mathrm{CO}_{2}$ atmosphere.

The differentiated $\mathrm{C} 2 \mathrm{C} 12$ myotubes were induced as descirbed before [19]. Generally, to induce the development of myotubes in $\mathrm{C} 2 \mathrm{C} 12$ cells, the media was changed with differentiated media, which were prepared with fresh DMEM supplemented with $2 \%$ horse serum and $1 \% \mathrm{P} / \mathrm{S}$, and continued to incubate for 4 days. After that, the cell morphology was observed and marker proteins (MYH1 and MyoD1) were determined by western blot. To induce the insulin resistance in differentiated $\mathrm{C} 2 \mathrm{C} 12$ myotubes, the cells were starved in serum-free DMEM for $4 \mathrm{~h}$, and then incubated with $0.2 \mathrm{mM}$ PA for $24 \mathrm{~h}$.

\section{Animals}

Male ob/ob mice (8-10 weeks) and same background C57BL/6 mice were purchased from Tengxin Biotechnology Co. (Chongqing, China), which were allowed ad libitum access to food and water unless otherwise stated, and rooms were maintained at $22{ }^{\circ} \mathrm{C}$ and $50 \%$ humidity on a 12-h light/dark cycle. The mice were administrated with $10 \mathrm{mg} / \mathrm{kg}$ trilobatin (intragastric, i.g.) once for each day for continued 4 weeks, and the control mice were treated with same volume of in phosphate-buffered saline (PBS). Before dissection, the mice were euthanatized by $\mathrm{CO}_{2}$ inhalation, and gastrocnemius (the fast-glycolytic) muscles were isolated, froze in liquid nitrogen, and stored at $-80{ }^{\circ} \mathrm{C}$. All animals' experiments were carried out in accordance with the principles and guidelines of the Chinese Council Animal Care and also approved by the Institutional Animal Care and Use Committee at Chongqing Science and Technology Committee.

\section{Glucose tolerance test}

Glucose tolerance test (GTT) was performed as previously described [20]. After the ob/ob mice were treated with $10 \mathrm{mg} / \mathrm{kg}$ trilobatin (i. g.) once for each day for continued 4 weeks, the mice were fasted overnight $(12 \mathrm{~h})$, $2 \mathrm{~g} / \mathrm{kg}$ glucose was administrated intragastrically, blood samples were collected from tail vein at $0,15,30,60$ and 120 min respectively, and the blood glucose was determined with One Touch Ultra Mini Blood Glucose Monitoring System (Johnson, Life Scan, Inc., Milpitas, CA, USA). 


\section{Palmitate solution preparation}

BSA-bound palmitate was prepared according to the procedure described previously [21]. Palmitate was firstly dissolved in $0.1 \mathrm{M} \mathrm{NaOH}$ to a concentration of $75 \mathrm{mM}$ by heating at $70{ }^{\circ} \mathrm{C}$ in a shaking water bath, and then the stock solution was complexed with $5 \%$ fatty acid-free bovine serum albumins (BSA; Ameresco, Solon, Ohio, USA) in PBS at a ratio of $8: 1(\mathrm{v} / \mathrm{v})$ at $56{ }^{\circ} \mathrm{C}$ in a shaking water bath. After filtration $(0.2 \mu \mathrm{m}$ membrane filter), this solution was stored at $-20{ }^{\circ} \mathrm{C}$ and used within 2 weeks. The same concentration of $\mathrm{NaOH}$ mixed with $10 \%$ FFAfree BSA was used as a control.

\section{Glucose uptake}

Glucose uptake in differentiated $\mathrm{C} 2 \mathrm{C} 12$ myotubes was measured by adding 2-NBDG, a fluorescent D-glucose analog to trace the uptake of glucose directly $[22,23]$. Generally, after the differentiated $\mathrm{C} 2 \mathrm{C} 12$ myotubes were starved in serum-free DMEM for $4 \mathrm{~h}$, and then treated with $0.2 \mathrm{mM}$ palmitate in the presence or absence of indicated concentrations of trilobatin for $24 \mathrm{~h}$, the cells were starved in KRBH for $3 \mathrm{~h}$, and then incubated without or with $100 \mathrm{nM}$ insulin for $30 \mathrm{~min}$, after that, 2-NBDG with a final concentration as $100 \mu \mathrm{M}$ was added and continued to incubate for $30 \mathrm{~min}$. After incubation, free 2-NBDG was washed out 3 times with PBS, and fluorescence densities in cell monolayers were measured with a fluorescence microplate reader (TECAN, Swiss) at an excitation wavelength of $475 \mathrm{~nm}$ and an emission wavelength of $550 \mathrm{~nm}$. The protein concentration of each sample was determined by the BCA method. Results were normalized by $\mathrm{mg}$ of total protein.

\section{Protein extraction}

After washed once with ice-cold PBS, the skeletal muscle tissues or cells were homogenized with hand held homogenizer (Biospec, Bartlesville, OK, USA) for $10 \mathrm{~s}$ and incubated on ice for 40-60 min in a modified RIPA buffer in the presence of $1 \%$ protease/phosphatase inhibitor cocktail, and the protein concentrations were measured with BCA protein assay kit from Beyotime (Shanghai, China).

To prepare the membrane and cytoplasm proteins, after the gastrocnemius muscles or cells were washed with PBS, the proteins were obtained by using plasma membrane protein extraction kit and nuclear/cytosolic fractionation kit from Beyotime (Shanghai, China) respectively according to the suggestions from the supplier. Generally, after the gastrocnemius muscles (which were cut into small pieces before use) or cells were incubated with membrane protein extraction reagent $\mathrm{A}$ in the ice bath for 10-15 min, and homogenized 30-50 times, the lysates were centrifuged for $10 \mathrm{~min}$ at $700 \times g$ and at
$4{ }^{\circ} \mathrm{C}$ to remove the nucleus and unfragmented cells. The cell membrane fragments were precipitated by centrifugation at $14,000 \times g$ and at $4{ }^{\circ} \mathrm{C}$ for $30 \mathrm{~min}$, and the supernatant is absorbed as cytoplasmic protein. And then, the precipitate was adding $200 \mu \mathrm{L}$ membrane protein extraction reagent $B$ and was re-suspended at maximum speed of Vortex for $10 \mathrm{~s}$, followed by an ice bath for $15 \mathrm{~min}$. The lysates were centrifuged at $14,000 \times g$ and at $4{ }^{\circ} \mathrm{C}$ for $5 \mathrm{~min}$, the supernatants were collected and used as the membrane proteins. After the proteins were quantified with BCA protein assay kit from Beyotime (Shanghai, China). Western blot was performed to determine GLUT4 expression on the plasma membrane and cytoplasm. The membrane marker Na, K-ATPase was used as a control in this study.

\section{Immunohistochemistry}

After the mice were administrated with $10 \mathrm{mg} / \mathrm{kg}$ trilobatin for 4 weeks (once for each day), the skeletal muscle tissues were isolated and fixed (10\% formalin solution in $0.1 \mathrm{M}$ PBS), frozen at $-80{ }^{\circ} \mathrm{C}$ overnight, and cut into $10 \mu \mathrm{m}$ sections on a freezing microtome (Leica, Nussloch, Germany). The sections were permeabilized in $0.1 \%$ Triton X-100 in PBS and blocked in 1\% BSA in PBS before incubation with the primary antibody. After stained with GLUT4 antibody (ab654, Abcam Inc. Cambridge, MA, USA) and together with DAPI nuclear stain (Invitrogen, CA, USA). Fluorescence images were acquired using a confocal microscope (Nikon, Tokio, Japan).

\section{Western blot}

Proteins $(20-30 \mu \mathrm{g})$ were subjected to $10 \%$ SDS-PAGE and then transferred to a PVDF membrane (Immobilon P; Millipore, MA, USA), and the membranes were then blocked for $2 \mathrm{~h}$ at room temperature with 5\% BSA in TBST (20 mM Tris, $150 \mathrm{mM} \mathrm{NaCl}, 2.7 \mathrm{mM} \mathrm{KCl}, 0.1 \%$ Tween 20, pH 7.4). The membranes were next immunoblotted with primary antibodies at dilutions of 1:500 to 1:2000. Specific total or phospho-proteins were visualized after subsequent incubation with a 1:10,000 dilution of anti-mouse or rabbit IgG conjugated to horseradish peroxidase. Excess antibody was washed off with TBST, and immunoreactivity was detected using ECL western blotting reagent (Millipore, MA, USA). Signal bands were quantified by densitometric analysis using ImageJ software (available from NIH at https://imagej.nih.gov/ij/) after scanning the blotted membrane. Three independent experiments were performed for each condition.

\section{Statistical analysis}

The data are expressed as means \pm SD. Statistical comparisons between two groups were carried out 
using Student's $t$-test or one-way analysis of variance (ANOVA), and one-way ANOVA with Bonferroni posthoc test for multiple comparisons. The differences were considered significant when $p<0.05$.

\section{Results}

Trilobatin prevented the palmitate-induced decrease of glucose uptake in $\mathrm{C} 2 \mathrm{C} 12$ myotubes

It has been established that the development of myoblasts is achieved with the expression of some myoblast-specific transcription factors, including myogenic determination protein 1 (MYOD1), myogenic factor 5 (MYF5), myogenin (MYOG) and myogenic factor 6 (MRF6) and some structural and enzymatic musclespecific proteins such as myosin heavy chain 1 (MYH1), the main motor protein in muscle filaments [24]. In this study, $\mathrm{C} 2 \mathrm{C} 12$ myoblasts were firstly incubated with differentiated media (DMEM supplied with $2 \%$ horse serum and $1 \% \mathrm{P} / \mathrm{S}$ ) to induce the development of myotubes as described in "Methods", the results demonstrated that the myoblasts were induced from human fibroblasts, and the myotube-like muti-nuclear structure were developed, which were confirmed by observing the morphology (Additional file 1: Figure S1A), detecting the protein markers MYH1 (Additional file 1: Figure S1B) and MYOD1 (Additional file 1: Figure S1C) of myotubes with western blot assay.

To verify the effect of trilobatin on insulin resistance, we reproduced a classic cellular model of insulin resistance in differentiated $\mathrm{C} 2 \mathrm{C} 12$ myotubes as described before [25]. Data revealed that treatment with palmitate attenuated insulin-stimulated glucose uptake (Fig. 1a), the phosphorylation of IRS-1 at Ser 307 (Fig. 1b) and Ser 612 (Fig. 1c), and AKT at Thr 308 (Fig. 1d) and Thr 473 (Fig. 1e) in a dose-dependent manner in $\mathrm{C} 2 \mathrm{C} 12$ myotubes.

To determine the potential impact of trilobatin on glucose uptake in insulin-resistant cells, the differentiated $\mathrm{C} 2 \mathrm{C} 12$ myotubes were incubated with $0.2 \mathrm{mM}$ palmitate in the presence or absence of $0,0.1,1.0$ or $10 \mu \mathrm{M}$ trilobatin for $24 \mathrm{~h}$. After the cells were stimulated with $100 \mathrm{nM}$ insulin for $30 \mathrm{~min}, 2-\mathrm{NBDG}$ was added and

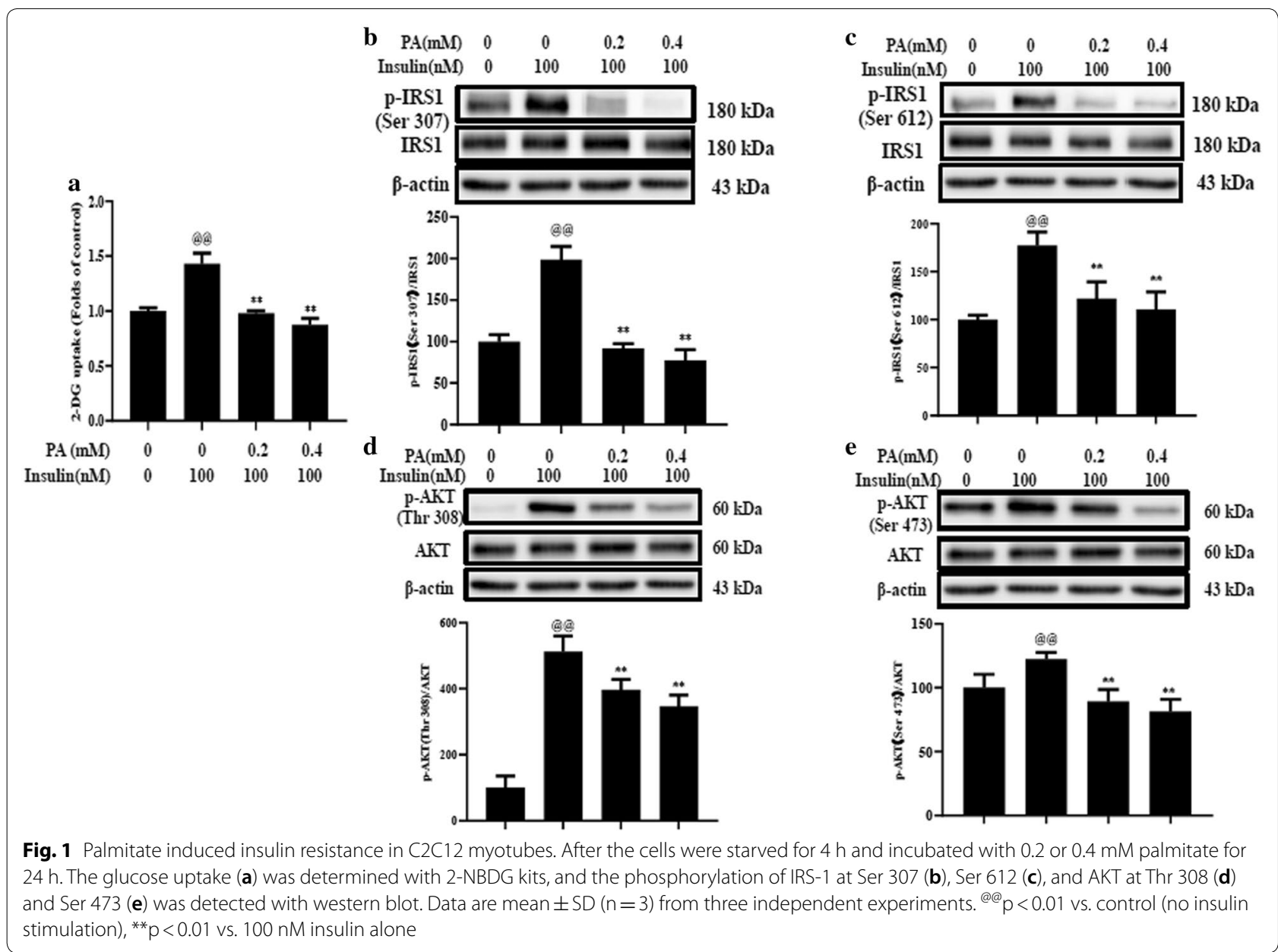


incubated for another $30 \mathrm{~min}$, and the glucose uptake was determined according to the suggestions from the supplier. The results demonstrated that treatment with palmitate induced a significant decrease of the uptake of 2-NBDG in C2C12 myotubes $(\mathrm{p}<0.01)$, but incubation with trilobatin prevented that in a dose-dependent manner ( $\mathrm{p}<0.01)$ (Fig. 2).

\section{Trilobatin regulated the phosphorylation of IRS1 and Akt} in palmitate-treated $\mathrm{C} 2 \mathrm{C} 12$ myotubes

To observe the effect of trilobatin on insulin signaling molecules under the condition of insulin resistance, we determined the phosphorylation of insulin receptor substrate 1 (IRS1) and its downstream molecule AKT in palmitate-treated $\mathrm{C} 2 \mathrm{C} 12$ myotubes, the results showed that trilobatin treatment recovered the phosphorylation of IRS1 at Ser 612 (Fig. 3a), Ser 307 (Fig. 3b) and AKT at Thr 308 (Fig. 3c) under stimulation with insulin, but there was no significant impact on the phosphorylation of AKT at Ser 473 (Fig. 3d).

\section{Trilobatin regulated the expression and distribution of GLUT4 in palmitate-treated $\mathrm{C} 2 \mathrm{C} 12$ myotubes}

To probe the actions of trilobatin on that in $\mathrm{C} 2 \mathrm{C} 12$ myotubes challenged by palmitate, we determined the protein levels of GLUT4 in membrane and cytoplasm in palmitate-treated cells in the presence or absence of

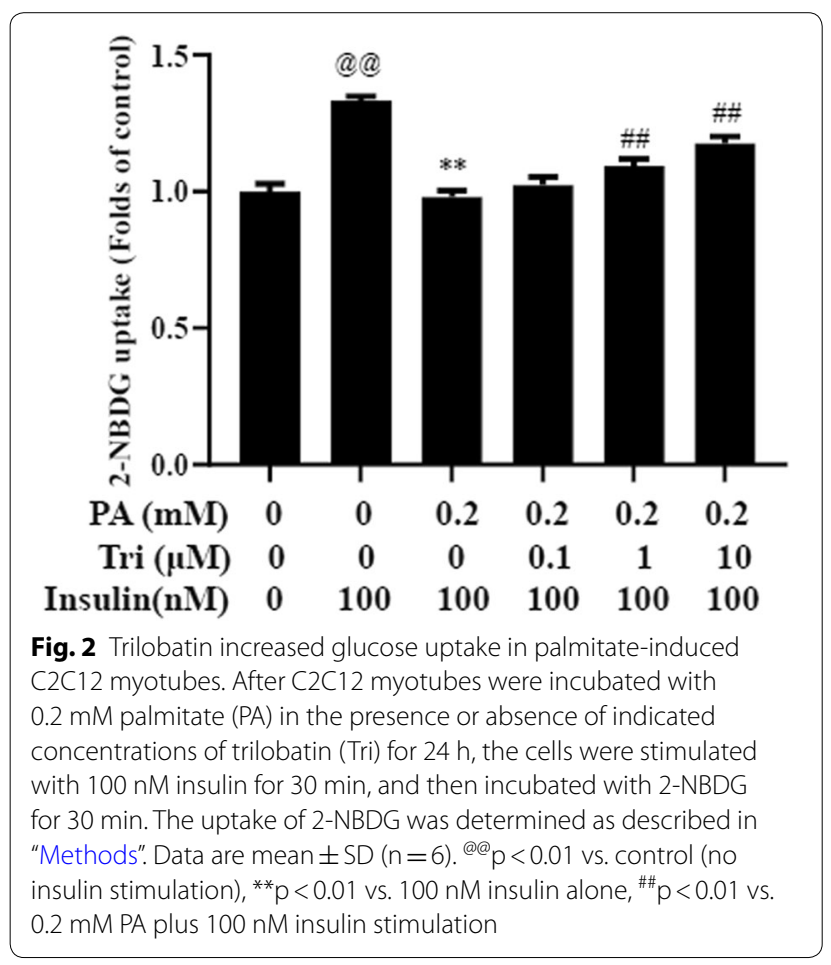

trilobatin. Data demonstrated that, compared with palmitate treatment alone, combination of palmitate and trilobatin increased the protein level of GLUT4 in the plasm membrane (Fig. 4a), but decreased the protein level of GLUT4 in the cytoplasm (Fig. 4b) in a dosedependent manner. These results clearly indicated that treatment with trilobatin accelerated the translocation of GLUT4 from cytoplasm to plasma membrane. Consistence with this result, the ratio of membrane/ cytoplasm of GLUT4 protein level was increased by trilobatin in a dose-dependent manner in palmitatetreated $\mathrm{C} 2 \mathrm{C} 12$ myotubes (Fig. 4c).

\section{PI3K plays an essential role in trilobatin improving insulin resistance}

To probe the cell signaling transduction, we determined the effect of pre-incubation with LY294002, a PI3K inhibitor, on the uptake of glucose in palmitate-treated $\mathrm{C} 2 \mathrm{C} 12$ myotubes and the distribution of GLUT4 in plasma membrane and cytoplasm. The results revealed that pre-treatment with LY294002 prohibited the effects of trilobatin on glucose uptake (Fig. 5a), the distribution of GLUT4 (Fig. 5b-d) under insulin stimulation in insulin-resistant $\mathrm{C} 2 \mathrm{C} 12$ myotubes.

\section{Trilobatin improved insulin resistance in ob/ob mice}

The increasing evidence indicates that ob/ob mice are a reasonable experimental model of obesityinduced insulin resistance [26, 27]. In this study, we first observed the effects of trilobatin on body weight, food, and water drinking, data showed that treatment with $10 \mathrm{mg} / \mathrm{kg}$ trilobatin (i. g.) for 4 weeks had no significant impact on the body weight (Fig. 6a, $F=315.77$ ), change of body weight (Fig. 6b, $F=0.538$ ), food (Fig. 6c, $\mathrm{F}=75.21)$ and water drinking (Fig. $6 \mathrm{~d}, \mathrm{~F}=6.612) \mathrm{in} \mathrm{ob} /$ ob mice.

At present, we also determined the influence of trilobatin on insulin resistance in ob/ob mice, the results demonstrated that treatment with $10 \mathrm{mg} / \mathrm{kg}$ trilobatin (intragastric, i.g.) for 4 weeks noticeably decreased fasting blood glucose (Fig. 7a) and insulin in serum (Fig. 7b), which was confirmed by the homeostasis model assessment of insulin resistance (HOMA-IR), a simple and efficient tool to evaluate the syndrome of insulin resistance (Fig. 7c). The results from the glucose tolerance test (GTT) showed that administration with trilobatin for 4 weeks significantly improved insulin resistance in ob/ob mice (Fig. 7d, e, p < 0.05, F = 0.695). 
$\mathbf{a}$

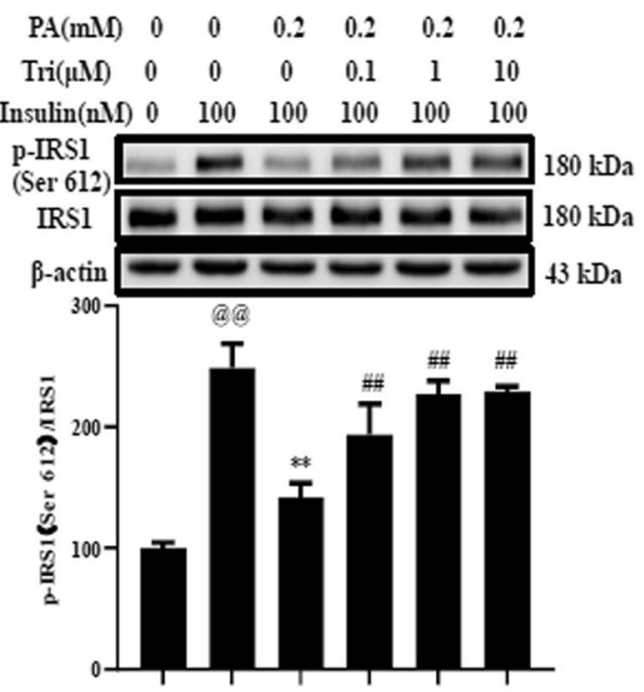

c

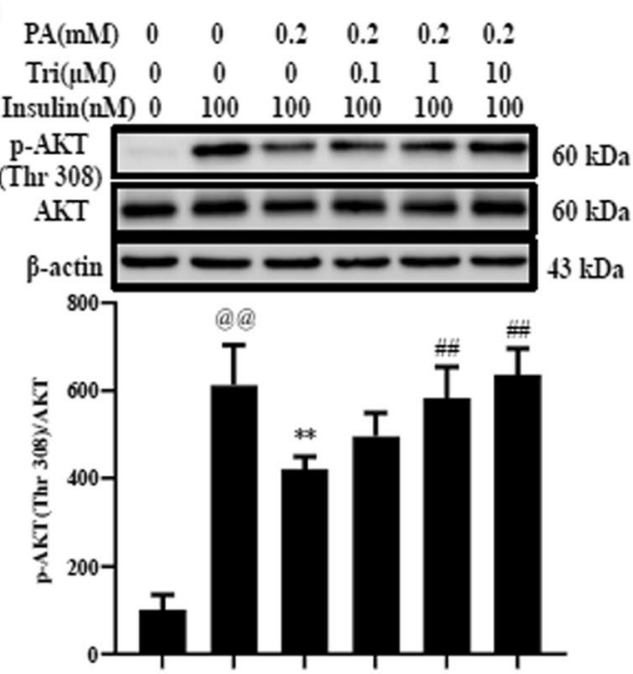

b

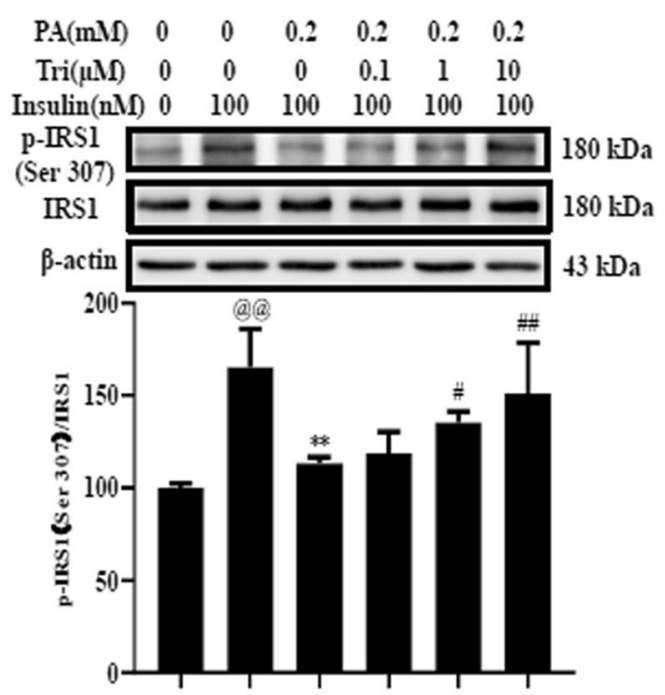

$\begin{array}{lllllll}\text { d } \operatorname{PA}(\mathrm{mM}) & 0 & 0 & 0.2 & 0.2 & 0.2 & 0.2\end{array}$

$\begin{array}{lllllll}\operatorname{Tri}(\mu \mathrm{M}) & 0 & 0 & 0 & 0.1 & 1 & 10\end{array}$

$\begin{array}{lllllll}\text { Insulin(nM) } & 0 & 100 & 100 & 100 & 100 & 100\end{array}$
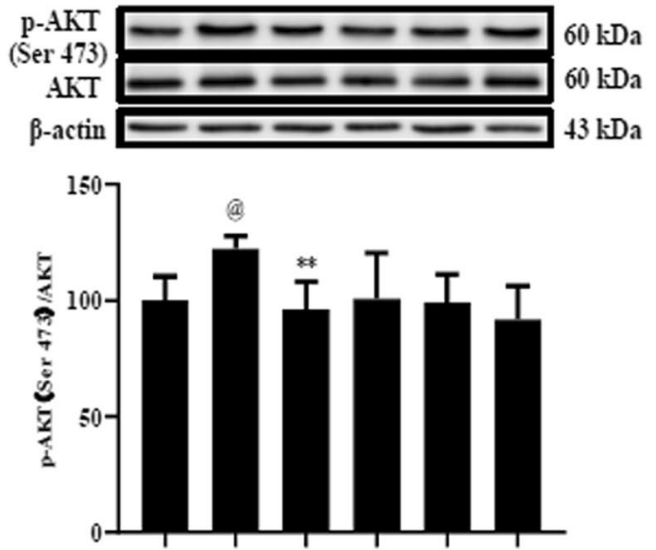

Fig. 3 Trilobatin regulated the phosphorylation of IRS1 at Ser612 (a), Ser307 (b) and AKT at Thr 308 (c), Ser 473 (d) in palmitate-induced C2C12 myotubes. After C2C12 myotubes were incubated with $0.2 \mathrm{mM}$ palmitate (PA) without or with indicated doses of trilobatin (Tri) for $24 \mathrm{~h}$, the cells were washed once and stimulated with $100 \mathrm{nM}$ insulin for $15 \mathrm{~min}$. The cell lysates were used to determine the expression and phosphorylation of IRS1 at Ser 612 (a), Ser 307 (b) and AKT at Thr 308 (c), Ser 473 (d). Data are mean \pm SD from three independent experiments. ${ }^{@} p<0.01$ vs. control (no insulin stimulation), ${ }^{* *} \mathrm{p}<0.01$ vs. $100 \mathrm{nM}$ insulin alone, ${ }^{\# \#} \mathrm{p}<0.01$ vs. $0.2 \mathrm{mM}$ PA plus $100 \mathrm{nM}$ insulin stimulation

Trilobatin regulated the phosphorylation of IRS1 and Akt in muscle tissue of ob/ob mice

After ob/ob mice were administrated with $10 \mathrm{mg} / \mathrm{kg}$ trilobatin (i. g.) for 4 weeks, we found that trilobatin significantly improved the deleterious effect induced by obesity on the phosphorylation of IRS1 at Ser 612 (Fig. 8a) and Ser 307 (Fig. 8b), and Akt at Thr 308 (Fig. 8c), but treatment with $10 \mathrm{mg} / \mathrm{kg}$ trilobatin for 4 weeks had no effect on the phosphorylation of AKT at Ser 473 (Fig. 8d) in the skeletal muscle tissue of ob/ob mice.
Trilobatin adjusted the expression and translocation of GLUT4 in the skeletal muscle of ob/ob mice

Insulin resistance induced a remarkably change in the expression and distribution of GLUT4 in skeletal muscle tissue $[5,28]$. At present, after treated with $10 \mathrm{mg} / \mathrm{kg}$ trilobatin for 4 weeks, we determined the expression and translocation of GLUT4 in the skeletal muscle from ob/ ob mice. The results showed that, compared to the same age of C57BL6 mice, the total protein of GLUT4 (Fig. 9a) was dramatically decreased, this phenomenon was also 

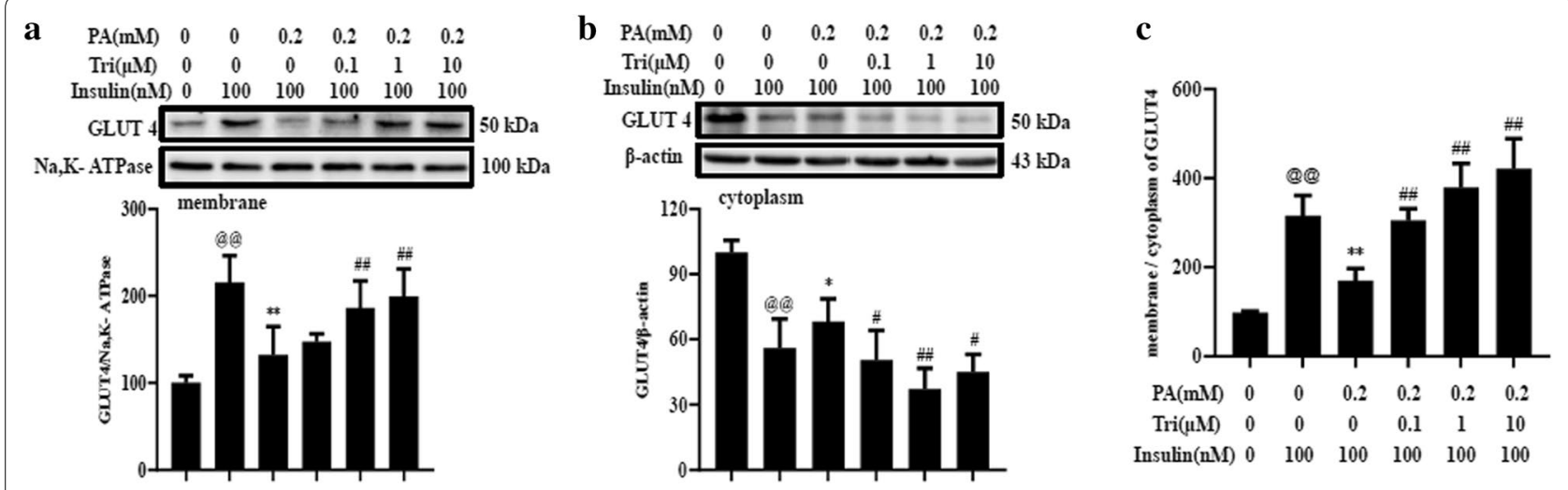

Fig. 4 Trilobatin regulated the expression and translocation of GLUT4 in palmitate-treated C2C12 myotubes. After the differentiated C2C12 myotubes were incubated with $0.2 \mathrm{mM}$ palmitate (PA) without or with indicated doses of trilobatin (Tri) for $24 \mathrm{~h}$, the cells were washed once and stimulated with $100 \mathrm{nM}$ insulin for $15 \mathrm{~min}$. The cell lysates were used to determine the expression of GLUT4 in membranes (a) and cytoplasm (b), and the ratio of GLUT4 in membrane and cytoplasm was calculated (c). Data are mean \pm SD from three independent experiments. ${ }^{@} \mathrm{p}<0.01$ vs. control (no insulin stimulation), ${ }^{*} p<0.05,{ }^{* *} p<0.01$ vs. $100 \mathrm{nM}$ insulin alone, ${ }^{\# \#} \mathrm{p}<0.01$ vs. $0.2 \mathrm{mM}$ PA plus $100 \mathrm{nM}$ insulin stimulation

$\mathbf{a}$

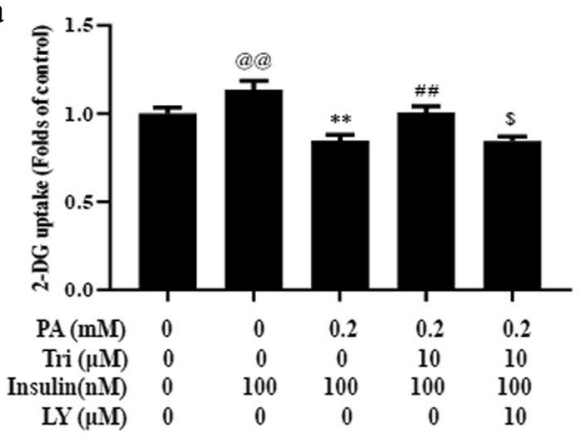

$\begin{array}{rccccc}\text { PA }(\mathrm{mM}) & 0 & 0 & 0.2 & 0.2 & 0.2 \\ \operatorname{Tri}(\mu \mathrm{M}) & 0 & 0 & 0 & 10 & 10 \\ \text { Insulin(nM) } & 0 & 100 & 100 & 100 & 100 \\ \text { LY }(\mu \mathrm{M}) & 0 & 0 & 0 & 0 & 10 \\ \text { GLUT } 4 & & & & & \end{array}$

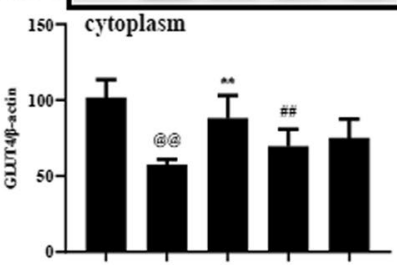

b

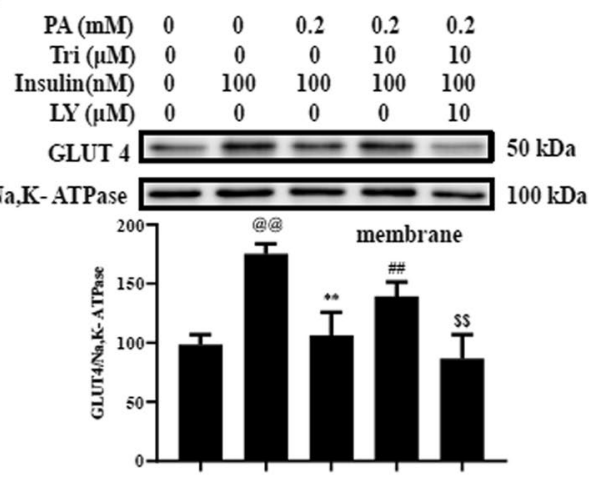

d

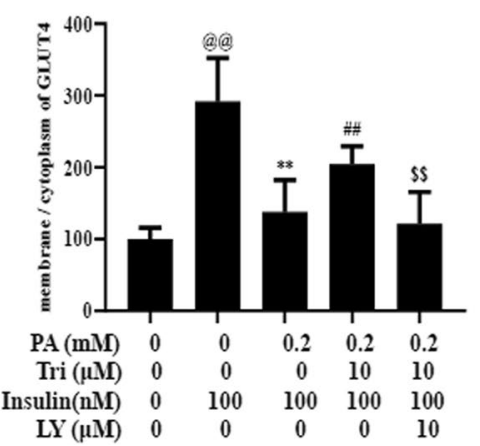

Fig. 5 LY294002, an PI3K inhibitor, prevented the effects of trilobatin on glucose uptake and GLUT4 distribution in insulin-resistant C2C12 myotubes. After C2C12 myotubes were incubated with $0.2 \mathrm{mM}$ palmitate (PA) without or with indicated doses of trilobatin (Tri) for $24 \mathrm{~h}$, the cells were washed once and stimulated with $100 \mathrm{nM}$ insulin for $30 \mathrm{~min}$ in the presence or absence of $10 \mu \mathrm{M} \mathrm{LY} 294002$ (LY), and then incubated with 2-NBDG for $30 \mathrm{~min}$. a The uptake of 2-NBDG was determined as described in "Methods". b, c the protein of GLUT4 in membrane and cytoplasm was detected with western blot. $\mathbf{d}$ The ratio of GLUT4 in membrane and cytoplasm was calculated. Data are mean \pm SD from three independent experiments. $@ p<0.01$ vs. control (no insulin stimulation), ${ }^{* *} p<0.01$ vs. $100 \mathrm{nM}$ insulin alone, ${ }^{\# \#} p<0.01$ vs. 0.2 mM PA with 100 nM insulin stimulation, ${ }^{\$} p<0.05,{ }^{\$ \$} p<0.01$ vs. $0.2 \mathrm{mM}$ PA combined with $10 \mu \mathrm{M}$ Trilobatin and $100 \mathrm{nM}$ insulin 

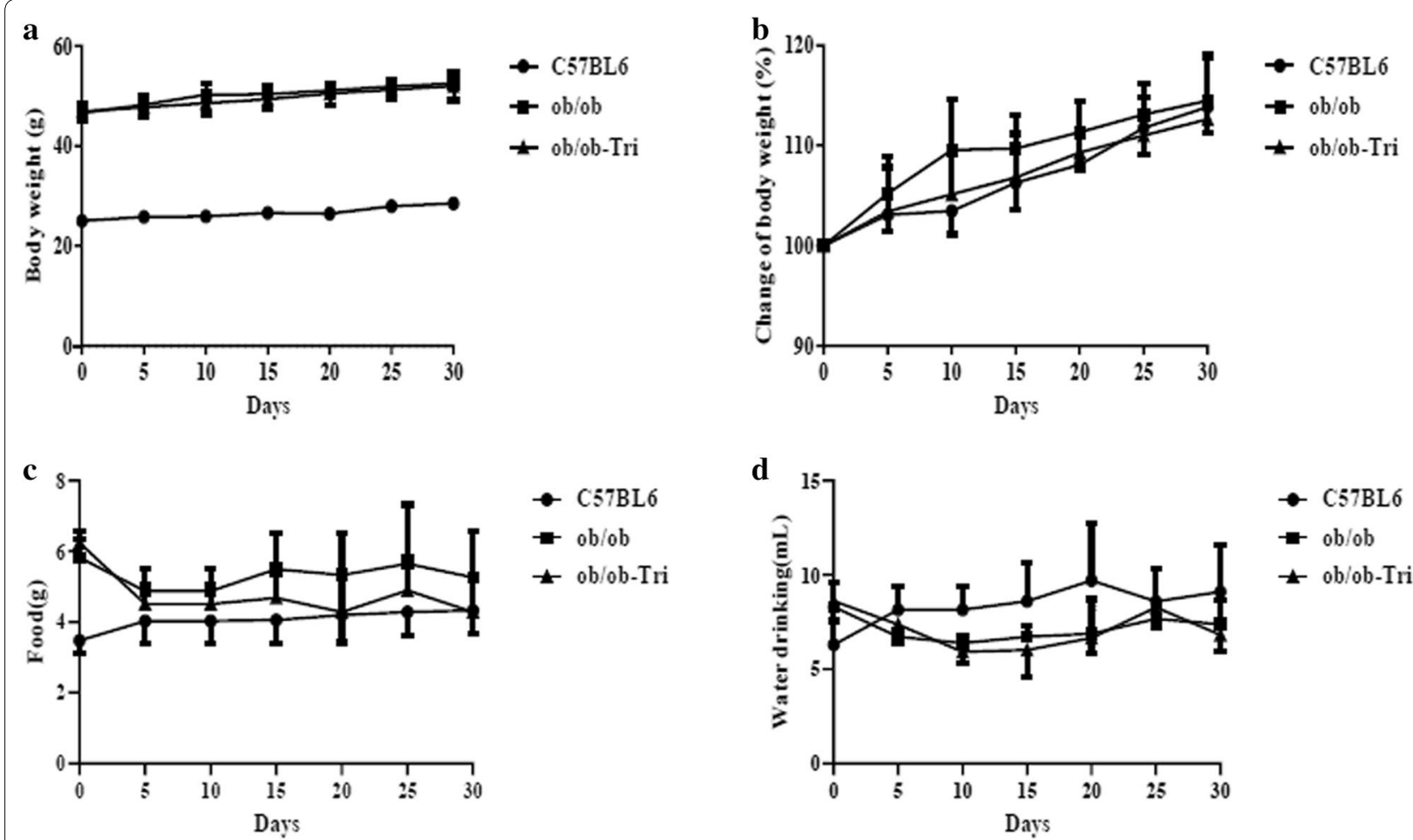

Fig. 6 Effects of trilobatin on body weight, food and water drinking in ob/ob mice. Twenty male ob/ob mice were separated to two groups randomly, which were control (ob/ob) and trilobatin (ob/ob-Tri), ten same age of C57BL/6 male mice were used as negative control (C57BL6) in this study. During treatment with $10 \mathrm{mg} / \mathrm{kg}$ (intragastric, i.g.), the body weight (a), change of body weight (b), food (c) and water drinking (d) were monitored in ob/ob mice. Data are mean $\pm S D(n=10)$

observed in plasma membrane (Fig. 9b) and cytoplasm (Fig. 9c). But after administrated with $10 \mathrm{mg} / \mathrm{kg}$ trilobatin (i. g.) for 4 weeks, the protein level of GLUT4 in the skeletal muscle tissue of ob/ob mice was significantly recovered (Fig. 9a-d).

\section{Discussion}

It had been shown that IRS1, widely expressed in mammalian myocytes, was a direct physiological substrate of the insulin receptor and played an important role in insulin signal transmission, the phosphorylation of IRS1 on tyrosine residues could interact with phosphatidylinositol-3 kinase (PI3K), which phosphorylates phosphatidylinositol 2 phosphates (PIP2) into phosphatidyl-inositol 3 phosphates (PIP3), and recruited Akt to the plasma membrane through the plextrin homology (PH) domain. AKT then phosphorylated adenosine monophosphateactivated protein kinase (AMPK), an energy sensor in eukaryotic cells, which affected the translocation of GLUT4 to the plasma membrane [29, 30]. On the contrary, the dephosphorylation of IRS1 on tyrosine residues can potentially inactivate the whole process of insulin signal transduction, leading to insulin resistance [31].

Insulin resistance, a hallmark of obesity and type 2 diabetes, is characterized by the defect of insulin to stimulate glucose uptake and utilization in the liver, skeletal muscles and adipose tissues [1, 32]. It has become increasingly apparent that chronic elevation of plasma free fatty acids (FFAs) played an essential role in the impairment of insulin-stimulated glucose uptake in obesity and type 2 diabetes [33, 34]. Exposure of FFAs impaired glycogen synthesis and the transport and utilization of glucose in adipocytes, hepatocytes and skeletal muscle cells $[35,36]$. Furthermore, prolonged exposure of FFAs induced the production of inflammatory factors and the activation of Jun $\mathrm{N}$-terminal kinase (JNK), which accelerated $\beta$-oxidation of FFA, brought excessive electron flux in the mitochondrial respiratory chain, and subsequently caused the generation of reactive oxidant species (ROS) [37-39]. All these 

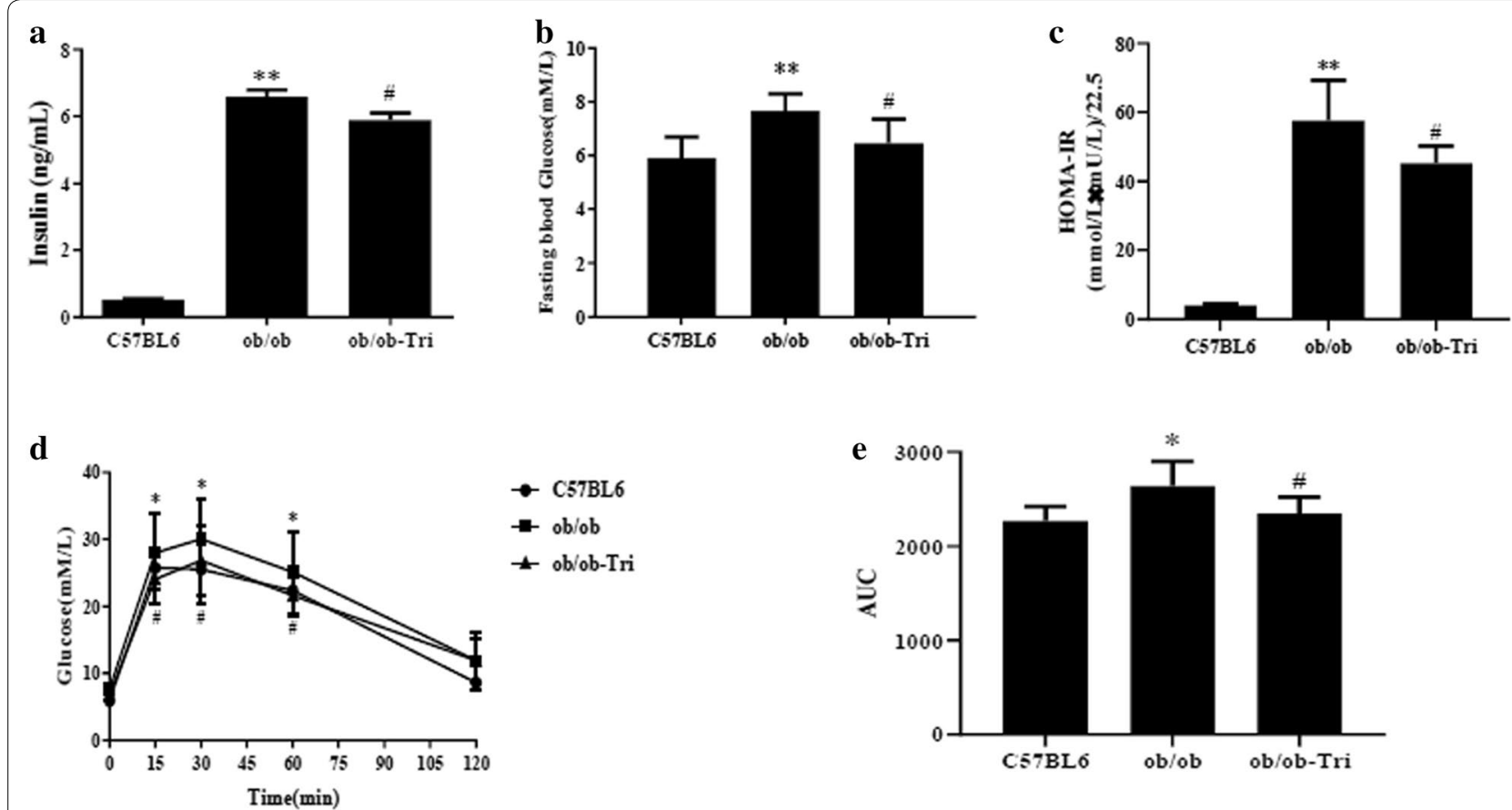

Fig. 7 Trilobatin improved insulin resistance in ob/ob mice. Twenty male ob/ob mice were separated to two groups randomly, which were control (ob/ob) and trilobatin (ob/ob-Tri), ten same age of C57BL/6 male mice were used as negative control (C57BL6) in this study. After ob/ob mice were administrated with $10 \mathrm{mg} / \mathrm{kg}$ trilobatin (i. g.) for 4 weeks, the insulin content in serum (a), fasting blood glucose (b) and glucose tolerance test (d) was measured, HOMA-IR (c) and AUC (e) were calculated. Data are mean $\pm \mathrm{SD}(n=10) .{ }^{*} p<0.05,{ }^{* *} p<0.01$ vs. C57BL6, ${ }^{\#} p<0.05$ vs. ob/ob

factors would damage the insulin signaling molecules by decreasing the phosphorylation of IRS and AKT, and impaired the expression and translocation of GLUT4, finally resulting in the defect of glucose uptake and utilization $[40,41]$. Despite such data, the underlying mechanisms remain to be explored and the promising compounds are still limited. At present, we observed that incubation with palmitate-induced insulin resistance by attenuating insulin-stimulated glucose uptake, the phosphorylation of IRS1 and AKT, and the distribution of GLUT4, but trilobatin prohibited these effects of palmitate in $\mathrm{C} 2 \mathrm{C} 12$ myotubes in a dose-dependent manner. The increasing data indicates that the PI3K/ AKT signal pathway played a pivotal role on the uptake and utilization of glucose, and the full activation of $\mathrm{AKT}$ in response to insulin was major mediated by the phosphorylation at Thr 308 and Ser 473 [42, 43]. In the present study, treatment with trilobatin recovered the phosphorylation of AKT at Thr 308, and LY294002, an inhibitor of PI3K, blocked almost the effect of trilobatin on glucose uptake in palmitate-treated $\mathrm{C} 2 \mathrm{C} 12$ myotubes. All these findings revealed that PI3K/AKT signaling pathway might be involved in trilobatin improving insulin resistance and glucose uptake in palmitatetreated $\mathrm{C} 2 \mathrm{C} 12$ myotubes.
It has been widely reported that GLUT4, mainly expressed in skeletal muscle and white adipose tissue, plays an important role in insulin-induced glucose uptake $[42,44]$. In these tissues, insulin induced the phosphorylation of IRS by binding to its tyrosine receptor. These phosphorylated proteins then activated PI3K by enhancing the phosphorylation of their downstream targets, including AKT and protein kinase C (PKC), which accelerated the translocation of GLUT4 from intracellular storage compartments to the plasma membrane [42, 43, 45]. In this study, our data demonstrated that consistence with the role on glucose uptake, incubation with trilobatin prevented the effects of palmitate on the translocation of GLUT4 from cytoplasm to plasma membrane in C2C12 myotubes, and in the presence of LY294002, the effect of trilobatin on the translocation of GLUT4 was inhibited evidently, suggested that AKT/GLUT4 signaling pathway was associated with trilobatin improving glucose uptake palmitate-treated $\mathrm{C} 2 \mathrm{C} 12$ myotubes.

To explore the effects of trilobatin on insulin resistance in vivo, we determined the role of trilobatin in ob/ ob mice, an interesting genetically obese mouse model characterized by hyperglycemia, hyperinsulinemia, 
a
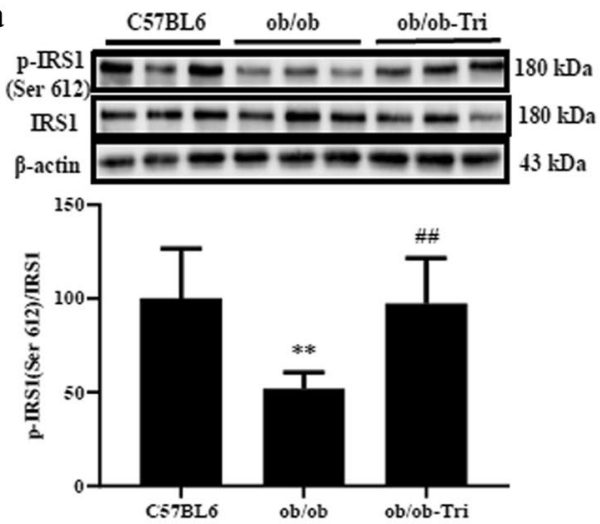

c
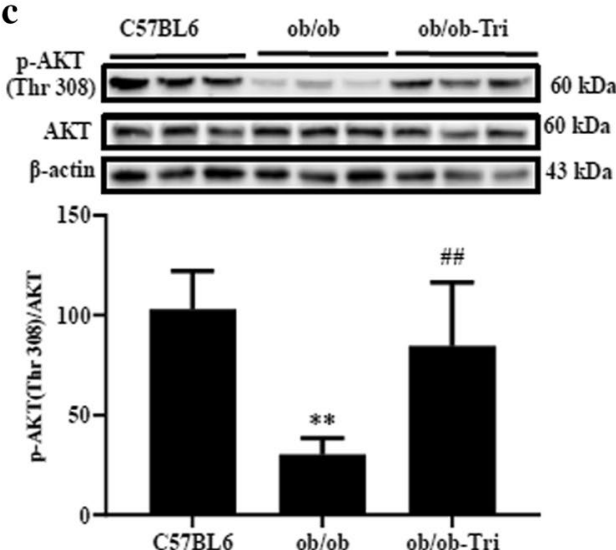

b
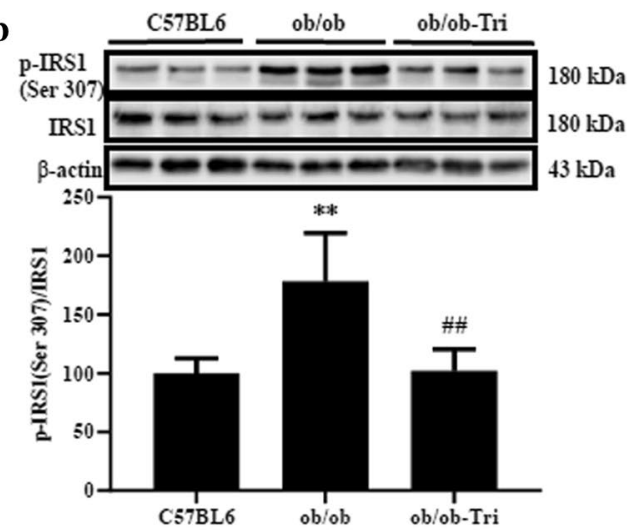

d
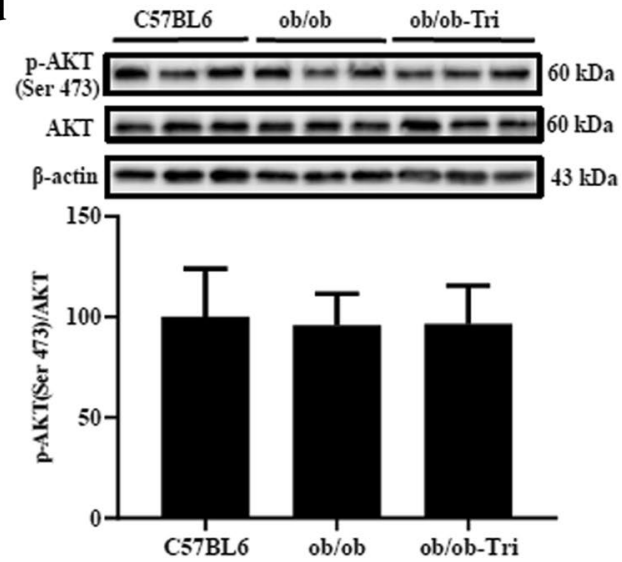

Fig. 8 Trilobatin regulated the phosphorylation of IRS1 and AKT in muscle tissues of ob/ob mice. After the ob/ob mice were administrated with $10 \mathrm{mg} / \mathrm{kg}$ trilobatin (i. g.) for 4 weeks, the skeletal muscles were collected, and proteins were extracted, the expression of IRS1 and AKT, the phosphorylation of IRS1 at Ser 612 (a) and Ser 307 (b), and the phosphorylation AKT at Thr 308 (c) and Ser 473 (d) were detected with western blotting assay. Data are mean \pm SD of randomly selected three from ten mice, and the experiments were repeated at least three times. ${ }^{* *} p<0.01 \mathrm{vs}$. C57BL6, ${ }^{\# \#}$ p $<0.01$ vs. ob/ob

and insulin resistance. The results demonstrated that administration with trilobatin for 4 weeks significantly decreased the contents of fasting blood glucose and insulin, improved insulin resistance, increased the phosphorylation of IRS1 at Ser 612, AKT at Thr 308 and decreased the phosphorylation of IRS1 at Ser 307, and recovered the expression and translocation of GLUT4 in $\mathrm{ob} / \mathrm{ob}$ mice. All these findings indicated that trilobatin might be a benefit to alleviate insulin resistance induced by obesity, and a promising compound for the treatment of obesity and type 2 diabetes.

\section{Conclusion}

There is now a wealth of evidence that IRS-AKTGLUT4 signal pathway plays an important role in the development of insulin resistance in obese animal models $[44,46]$. In the present study, we demonstrated that administration with trilobatin alleviated obesityinduced insulin resistance by decreasing the levels of fasting blood glucose and insulin, improving glucose tolerance, and these beneficial effects were associated with trilobatin ameliorating the defects of IRS1 and $\mathrm{AKT}$ phosphorylation, recovering the translocation of 


\section{a}

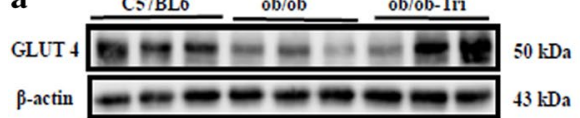

${ }^{150} 7$ total protein

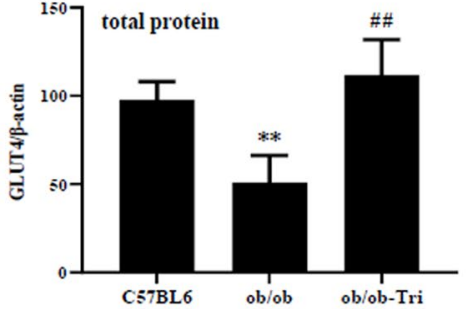

c

C57BL6 ob/ob ob/ob-Tri

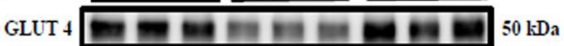

$\beta$-actin $\longrightarrow$ -

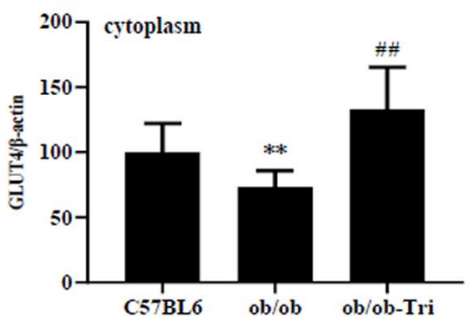

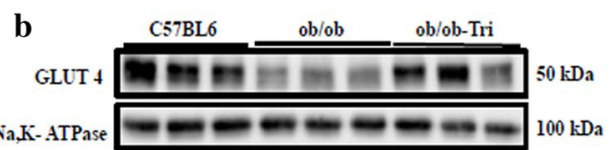

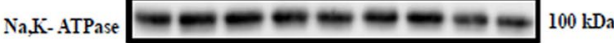

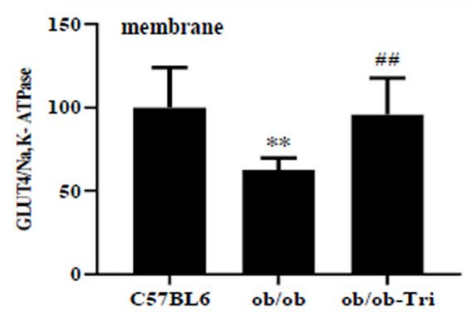

d
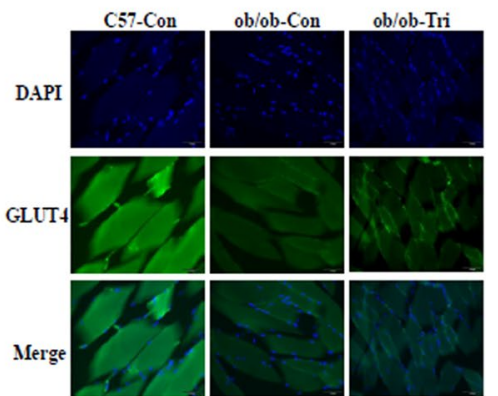

Fig. 9 Trilobatin affected the expression and distribution of GLUT4 in muscle tissue of ob/ob mice. After the ob/ob mice were administrated with $10 \mathrm{mg} / \mathrm{kg}$ trilobatin (i. g.) for 4 weeks, the expression (a), distribution of GLUT 4 in membranes (b) and cytoplasm (c) were detected by western blot or immunofluorescence $(\mathbf{d})$. Data are mean \pm SD of randomly selected three from ten mice, and the experiments were repeated at least three times. ${ }^{* *} p<0.01$ vs. C57BL6, ${ }^{\# \#} p<0.01$ vs. ob/ob

GLUT4 in ob/ob mice. The results of the current study strongly support the concept that the IRS-AKT-GLUT4 signaling pathway is involved in trilobatin improving insulin resistance in $\mathrm{C} 2 \mathrm{C} 12$ myotubes and ob/ob mice.

\section{Supplementary information}

Supplementary information accompanies this paper at https://doi. org/10.1186/s13020-020-00390-2.

Additional file 1. The differentiation of $\mathrm{C} 2 \mathrm{C} 12$ myotubes. After $\mathrm{C} 2 \mathrm{C} 12$ myoblasts were incubated with differentiated media as described in Methods. The myotubes were observed (A), and the protein markers MYH1 (B) and MyoD1 (C) were determined with western blot. Data are mean \pm SD from three independent experiments. ${ }^{*}, p<0.05,{ }^{* *}, p<0.01$ vs. control (0 day).

\section{Abbreviations}

BSA: Bovine serum albumins; GLUT4: Glucose transporter 4; GTT: Glucose tolerance test; HFD: High-fat diet; IR: Insulin resistance; 2-NBDG: 2-(N-(7-Nitrobenz2-oxa-1,3-diazol-4-yl) amino)-2-deoxyglucose; PKB: Protein kinase B; PKC: Protein kinase C; STZ: Streptozotocin.

\section{Acknowledgements}

This work was supported by the grants from Chongqing Science and Technology Committee (2017jcyjB0077), and the Innovative Research Team Development Program at the University of Chongqing (CXTDX201601031).

\section{Authors' contributions}

$L M, W L, L X G$, and WYC performed the experiments and analyzed the data; $\mathrm{LH}$ and YF were the major contributor in designing the research and writing the manuscript. All authors read and approved the final manuscript.

\section{Funding}

This work was supported by the grants from Chongqing Science and Technology Committee (2017jcyjB0077), and the Innovative Research Team Development Program at the University of Chongqing (CXTDX201601031).

\section{Availability of data and materials}

The datasets used and/or analyzed during the current study are available from the corresponding author on reasonable request.

\section{Ethics approval and consent to participate}

Not applicable.

\section{Consent for publication}

Not applicable.

\section{Competing interests}

The authors declare that they have no competing interests.

\section{Author details}

${ }^{1}$ Chongqing Key Lab of Medicinal Chemistry \& Molecular Pharmacology, Chongqing University of Technology, Hongguang Road 69, Ba'nan District, Chongqing 400054, China. ${ }^{2}$ College of Pharmacy and Bioengineering, Chongqing University of Technology, Chongqing 400054, China.

Received: 22 July 2020 Accepted: 4 October 2020

Published online: 12 October 2020 


\section{References}

1. Al-Sulaiti H, Diboun I, Agha MV, Mohamed FFS, Atkin S, Domling AS, et al. Metabolic signature of obesity-associated insulin resistance and type 2 diabetes. J Transl Med. 2019;17(1):348. https://doi.org/10.1186/s1296 7-019-2096-8.

2. Hagman E, Besor O, Hershkop K, Santoro N, Pierpont B, Mata M, et al. Relation of the degree of obesity in childhood to adipose tissue insulin resistance. Acta Diabetol. 2019;56(2):219-26. https://doi.org/10.1007/ s00592-018-01285-3.

3. DeFronzo RA, Gunnarsson R, Bjorkman O, Olsson M, Wahren J. Effects of insulin on peripheral and splanchnic glucose metabolism in noninsulindependent (type II) diabetes mellitus. J Clin Invest. 1985;76(1):149-55. https://doi.org/10.1172/JCl111938.

4. Thiebaud D, Jacot E, DeFronzo RA, Maeder E, Jequier E, Felber JP. The effect of graded doses of insulin on total glucose uptake, glucose oxidation, and glucose storage in man. Diabetes. 1982;31(11):957-63. https:// doi.org/10.2337/diacare.31.11.957

5. Fujiwara Y, Tsukahara C, Ikeda N, Sone Y, Ishikawa T, Ichi I, et al. Oleuropein improves insulin resistance in skeletal muscle by promoting the translocation of GLUT4. J Clin Biochem Nutr. 2017;61(3):196-202. https://doi. org/10.3164/jcbn.16-120.

6. Li Z, Zhu Y, Li C, Tang Y, Jiang Z, Yang M, et al. Liraglutide ameliorates palmitate-induced insulin resistance through inhibiting the IRS-1 serine phosphorylation in mouse skeletal muscle cells. J Endocrinol Invest. 2018;41(9):1097-102. https://doi.org/10.1007/s40618-018-0836-x.

7. Sanvee GM, Panajatovic MV, Bouitbir J, Krahenbuhl S. Mechanisms of insulin resistance by simvastatin in C2C12 myotubes and in mouse skeletal muscle. Biochem Pharmacol. 2019;164:23-33. https://doi. org/10.1016/j.bcp.2019.02.025.

8. Xiao Z, Zhang Y, Chen X, Wang Y, Chen W, Xu Q, et al. Extraction, identification, and antioxidant and anticancer tests of seven dihydrochalcones from Malus 'Red Splendor' fruit. Food Chem. 2017;231:324-31. https://doi. org/10.1016/j.foodchem.2017.03.111.

9. Duge de Bernonville T, Guyot S, Paulin JP, Gaucher M, Loufrani L, Henrion $D$, et al. Dihydrochalcones: implication in resistance to oxidative stress and bioactivities against advanced glycation end-products and vasoconstriction. Phytochemistry. 2010;71(4):443-52. https://doi.org/10.1016/j. phytochem.2009.11.004

10. Yang WM, Liu JK, Qin XD, Wu WL, Chen ZH. Antioxidant activities of three dihydrochalcone glucosides from leaves of Lithocarpus pachyphyllus. Z Naturforsch C J Biosci. 2004;59(7-8):481-4. https://doi.org/10.1515/ znc-2004-7-805.

11. Fan X, Zhang Y, Dong H, Wang B, Ji H, Liu X. Trilobatin attenuates the LPSmediated inflammatory response by suppressing the NF-kappaB signaling pathway. Food Chem. 2015;166:609-15. https://doi.org/10.1016/j. foodchem.2014.06.022

12. Yin S, Zhang $X$, Lai F, Liang T, Wen J, Lin W, et al. Trilobatin as an HIV-1 entry inhibitor targeting the HIV-1 Gp41 envelope. FEBS Lett. 2018;592(13):2361-77. https://doi.org/10.1002/1873-3468.13113.

13. Wang J, Huang Y, Li K, Chen Y, Vanegas D, McLamore ES, et al. Leaf extract from Lithocarpus polystachyus Rehd. Promote glycogen synthesis in T2DM mice. PLoS ONE. 2016;11(11):e0166557. https://doi.org/10.1371/journ al.pone.0166557.

14. Katsuda Y, Sasase T, Tadaki H, Mera Y, Motohashi Y, Kemmochi Y, et al. Contribution of hyperglycemia on diabetic complications in obese type 2 diabetic SDT fatty rats: effects of SGLT inhibitor phlorizin. Exp Anim. 2015;64(2):161-9. https://doi.org/10.1538/expanim.14-0084.

15. Wu CH, Ho YS, Tsai CY, Wang YJ, Tseng H, Wei PL, et al. In vitro and in vivo study of phloretin-induced apoptosis in human liver cancer cells involving inhibition of type II glucose transporter. Int J Cancer. 2009;124(9):2210-9. https://doi.org/10.1002/ijc.24189.

16. Figueiredo-Gonzalez M, Grosso C, Valentao P, Andrade PB. alphaGlucosidase and alpha-amylase inhibitors from Myrcia spp.: a stronger alternative to acarbose? J Pharm Biomed Anal. 2016;118:322-7. https:// doi.org/10.1016/j.jpba.2015.10.042.

17. Uto H. alpha-Glucosidase inhibitor acarbose and sequestome 1/A170/ p62 deficient mice: a promising therapy and unique model for nonalcoholic fatty liver disease. Hepatol Res. 2009;39(9):845-6. https://doi. org/10.1111/j.1872-034X.2009.00585.X.
18. Guo M, Li Y, Wang Y, Li Z, Li X, Zhao P, et al. eEF1A2 exacerbated insulin resistance in male skeletal muscle via PKCbeta and ER stress. J Endocrinol. 2019. https://doi.org/10.1530/JOE-19-0051.

19. Shen S, Liao Q, Zhang T, Pan R, Lin L. Myricanol modulates skeletal muscle-adipose tissue crosstalk to alleviate high-fat diet-induced obesity and insulin resistance. Br J Pharmacol. 2019. https://doi.org/10.1111/ bph.14802.

20. Lee YS, Cha BY, Saito K, Yamakawa H, Choi SS, Yamaguchi K, et al. Nobiletin improves hyperglycemia and insulin resistance in obese diabetic ob/ob mice. Biochem Pharmacol. 2010;79(11):1674-83. https://doi. org/10.1016/j.bcp.2010.01.034.

21. Liu J, Yin F, Xiao H, Guo L, Gao X. Glucagon-like peptide 1 receptor plays an essential role in geniposide attenuating lipotoxicity-induced beta-cell apoptosis. Toxicol In Vitro. 2012;26(7):1093-7. https://doi.org/10.1016/j. tiv.2012.07.004

22. Chen Y, Zhang J, Zhang XY. 2-NBDG as a marker for detecting glucose uptake in reactive astrocytes exposed to oxygen-glucose deprivation in vitro. J Mol Neurosci. 2015;55(1):126-30. https://doi.org/10.1007/s1203 1-014-0385-5

23. Zou C, Wang Y, Shen Z. 2-NBDG as a fluorescent indicator for direct glucose uptake measurement. J Biochem Biophys Methods. 2005;64(3):20715. https://doi.org/10.1016/j.jbbm.2005.08.001

24. Lluis F, Perdiguero E, Nebreda AR, Munoz-Canoves P. Regulation of skeletal muscle gene expression by p38 MAP kinases. Trends Cell Biol. 2006;16(1):36-44. https://doi.org/10.1016/j.tcb.2005.11.002.

25. Nieuwoudt S, Mulya A, Fealy CE, Martelli E, Dasarathy S, Naga Prasad SV, et al. In vitro contraction protects against palmitate-induced insulin resistance in C2C12 myotubes. Am J Physiol Cell Physiol. 2017:313(5):C575-C583583. https://doi.org/10.1152/ajpcell.00123.2017.

26. Belfiore F, Rabuazzo AM, lannello S, Vasta D, Campione R. Insulin resistance in the obese hyperglycemic (ob/ob) mouse. Failure of hyperinsulinemia to activate hepatic pyruvate kinase (PK). Metabolism. 1984;33(2):104-6. https://doi.org/10.1016/0026-0495(84)90119-7.

27. Clarke PV, Kissebah AH, Hope-Gill H, Vydelingum N, Tulloch B, Fraser TR. The role of calcium in insulin action. IV. Mechanism of insulin resistance in adipose tissue of obese (ob/ob) mice and old Wistar rats. Eur J Clin Invest. 1975;5(4):351-8. https://doi.org/10.1111/j.1365-2362.1975.tb00464.x.

28. Fang $P, Y u$ M, Zhang L, Wan D, Shi M, Zhu Y, et al. Baicalin against obesity and insulin resistance through activation of AKT/AS160/GLUT4 pathway. Mol Cell Endocrinol. 2017;448:77-86. https://doi.org/10.1016/j. mce.2017.03.027

29. Lima MH, Ueno M, Thirone AC, Rocha EM, Carvalho CR, Saad MJ. Regulation of IRS-1/SHP2 interaction and AKT phosphorylation in animal models of insulin resistance. Endocrine. 2002;18(1):1-12. https://doi.org/10.1385/ ENDO:18:1:01.

30. Ren L, Zhou X, Huang X, Wang C, Li Y. The IRS/PI3K/Akt signaling pathway mediates olanzapine-induced hepatic insulin resistance in male rats. Life Sci. 2019;217:229-36. https://doi.org/10.1016/j.lfs.2018.12.015.

31. Babu S, Krishnan M, Rajagopal P, Periyasamy V, Veeraraghavan V, Govindan $\mathrm{R}$, et al. Beta-sitosterol attenuates insulin resistance in adipose tissue via IRS-1/Akt mediated insulin signaling in high fat diet and sucrose induced type-2 diabetic rats. Eur J Pharmacol. 2020;873:173004. https://doi. org/10.1016/j.ejphar.2020.173004.

32. Smith U, Axelsen M, Carvalho E, Eliasson B, Jansson PA, Wesslau C. Insulin signaling and action in fat cells: associations with insulin resistance and type 2 diabetes. Ann NY Acad Sci. 1999;892:119-26. https://doi. org/10.1111/j.1749-6632.1999.tb07790.x.

33. Boden $\mathrm{G}$. Effects of free fatty acids (FFA) on glucose metabolism: significance for insulin resistance and type 2 diabetes. Exp Clin Endocrino Diabetes. 2003;111(3):121-4. https://doi.org/10.1055/s-2003-39781.

34. Christiansen E, Urban C, Merten N, Liebscher K, Karlsen KK, Hamacher A, et al. Discovery of potent and selective agonists for the free fatty acid receptor 1 (FFA(1)/GPR40), a potential target for the treatment of type II diabetes. J Med Chem. 2008;51(22):7061-4. https://doi.org/10.1021/ jm8010178.

35. Chavez JA, Summers SA. Characterizing the effects of saturated fatty acids on insulin signaling and ceramide and diacylglycerol accumulation in 3T3-L1 adipocytes and C2C12 myotubes. Arch Biochem Biophys. 2003;419(2):101-9. https://doi.org/10.1016/j.abb.2003.08.020. 
36. Hirabara SM, Curi R, Maechler P. Saturated fatty acid-induced insulin resistance is associated with mitochondrial dysfunction in skeletal muscle cells. J Cell Physiol. 2010;222(1):187-94. https://doi.org/10.1002/jcp.21936

37. Yuzefovych L, Wilson G, Rachek L. Different effects of oleate vs. palmitate on mitochondrial function, apoptosis, and insulin signaling in L6 skeletal muscle cells: role of oxidative stress. Am J Physiol Endocrinol Metab. 2010;299(6):E1096-E11051105. https://doi.org/10.1152/ajpendo.00238 .2010.

38. Nakamura S, Takamura T, Matsuzawa-Nagata N, Takayama H, Misu H, Noda $\mathrm{H}$, et al. Palmitate induces insulin resistance in $\mathrm{H} 4$ IIEC3 hepatocytes through reactive oxygen species produced by mitochondria. J Biol Chem. 2009;284(22):14809-18. https://doi.org/10.1074/jbc.M901488200.

39. Gao D, Nong S, Huang X, Lu Y, Zhao H, Lin Y, et al. The effects of palmitate on hepatic insulin resistance are mediated by NADPH Oxidase 3-derived reactive oxygen species through JNK and p38MAPK pathways. J Biol Chem. 2010;285(39):29965-73. https://doi.org/10.1074/jbc.M110.128694.

40. Kadotani A, Tsuchiya Y, Hatakeyama H, Katagiri H, Kanzaki M. Different impacts of saturated and unsaturated free fatty acids on COX-2 expression in C(2)C(12) myotubes. Am J Physiol Endocrinol Metab. 2009;297(6):E1291-1303. https://doi.org/10.1152/ajpendo.00293.2009.

41. Zhang Y, Yang S, Zhang M, Wang Z, He X, Hou Y, et al. Glycyrrhetinic acid improves insulin-response pathway by regulating the balance between the Ras/MAPK and PI3K/Akt pathways. Nutrients. 2019. https://doi. org/10.3390/nu11030604
42. Ducluzeau PH, Fletcher LM, Welsh Gl, Tavare JM. Functional consequence of targeting protein kinase B/Akt to GLUT4 vesicles. J Cell Sci. 2002;115(Pt 14):2857-66

43. Hill MM, Clark SF, Tucker DF, Birnbaum MJ, James DE, Macaulay SL. A role for protein kinase Bbeta/Akt2 in insulin-stimulated GLUT4 translocation in adipocytes. Mol Cell Biol. 1999;19(11):7771-81. https://doi.org/10.1128/ mcb.19.11.7771.

44. Li W, Liang X, Zeng Z, Yu K, Zhan S, Su Q, et al. Simvastatin inhibits glucose uptake activity and GLUT4 translocation through suppression of the IR/IRS-1/Akt signaling in C2C12 myotubes. Biomed Pharmacother. 2016;83:194-200. https://doi.org/10.1016/j.biopha.2016.06.029.

45. Egawa K, Maegawa H, Shi K, Nakamura T, Obata T, Yoshizaki T, et al. Membrane localization of 3-phosphoinositide-dependent protein kinase-1 stimulates activities of Akt and atypical protein kinase $C$ but does not stimulate glucose transport and glycogen synthesis in 3T3-L1 adipocytes. J Biol Chem. 2002;277(41):38863-9. https://doi.org/10.1074/jbc.M2031 32200 .

46. Sharma BR, Kim HJ, Rhyu DY. Caulerpa lentillifera extract ameliorates insulin resistance and regulates glucose metabolism in C57BL/KsJ-db/ $\mathrm{db}$ mice via PI3K/AKT signaling pathway in myocytes. J TransI Med. 2015;13:62. https://doi.org/10.1186/s12967-015-0412-5.

\section{Publisher's Note}

Springer Nature remains neutral with regard to jurisdictional claims in published maps and institutional affiliations.
Ready to submit your research? Choose BMC and benefit from:

- fast, convenient online submission

- thorough peer review by experienced researchers in your field

- rapid publication on acceptance

- support for research data, including large and complex data types

- gold Open Access which fosters wider collaboration and increased citations

- maximum visibility for your research: over $100 \mathrm{M}$ website views per year

At BMC, research is always in progress.

Learn more biomedcentral.com/submissions 